\title{
The Comparison Between Norotate and Promax Rotations of Biplot Simulation in The Management of Bali Cattle's Breeding Farms on Integrated Farming System
}

\author{
I Putu Sampurna1, Tjokorda Sari Nindhia ${ }^{2}$, I Made Sukada ${ }^{3}$ \\ ${ }^{1}$ Biostatistics Laboratory, Preventive Veterinary Medicine Department, Faculty of Veterinary \\ Medicine, Udayana University, Bali Indonesia. \\ Email: putu_sampurna@unud.ac.id \\ ${ }^{2}$ Biostatistics Laboratory, Preventive Veterinary Medicine Department, Faculty of Veterinary \\ Medicine, Udayana University, Bali Indonesia. \\ Email: sari_nindhia@unud.ac.id \\ ${ }^{3}$ Veterinary Public Health Laboratory, Preventive Veterinary Medicine Department, Faculty \\ of Veterinary Medicine, Udayana University, Bali Indonesia \\ Email: madesukada@unud.ac.id
}

Corresponding Author: putu_sampurna@unud.ac.id

\begin{abstract}
This study aims to determine the comparison between Norotate Rotation and Promax Rotation (90) of Biplot Simulation in the management of Bali Cattle Breeding Farms on Integrated Farming System (Simantri). It used to determine the difference of coordinates between the variables and also obtain the information about the difference in the proximity of the coordinates between livestock groups. The study conducted on Simantri who had livestock groups in Badung Regency, Bali in which the data collected were analyzed by factor analysis with Norotate Rotation and Promax Rotation (90). The variable of this study was a livestock management which included management of cows, calves, feed, cowshed, environmental,and the objects of the study were thelivestock groups. The Biplot simulation used to determine the coordinates of the livestock groups determined based on the Factor Scores Method Regression Analysis. The results with different rotations caused differences in the magnitude of the arrow angles and directions between management of cows, calves, feeds, cowshed and environmental which also followed by differences in the coordinate systems of the livestock groups. The angle between management of cows, calves, feeds, cowshed, and environmental do not show the magnitude of the correlation between them. It can be stated that the coordinates of Livestock groups on Promax Rotation (90) are more specific than Norotate Rotation, therefore it is easier to distinguish the different scores between the variables on the Livestock groups.
\end{abstract}

Keywords: Biplot, Rotation, Norotate, Promax, Simantri, Management, Cattle Bali, Livestock groups.

\section{INTRODUCTION}

Simantri (Integrated Farming

System) integrates agricultural activities with supporting sectors both vertically and horizontally according to the potential of each region by optimizing the utilization 
of existing local resources. Integration activities carried out are also oriented to agricultural business without waste (zero waste) and produce $4 \mathrm{~F}$ (food, feed, fertilizer, and fuel). The main activity is integrating the cultivation of plants and livestock, where plant waste processed for animal feed and feed reserves for dry season and animal waste (feces, urine) processed into biogas, bio urine, organic fertilizer and bio-pesticides. Indicators of the success of Simantri are the development of institutions and human resources, both agricultural officials and farmers. The creation of employment opportunities through the development of diversification of agricultural businesses and home industries, the development of intensification and extensification of farming, the process of increasing incentives for farming through increased production and efficiency of farming (fertilizer, feed, biogas, bio urine, biopesticides produced by themselves and the development of organic farming towards green economy[1]. Technically, it is a broad integration of agricultural activities including food crops, pulses and horticulture, livestock, fisheries, plantations and forestry plants in one area/location of activities. It is at the same time a pilot development model in accelerating technology transfer to rural communities. The dynamics and information about Simantri activities in the process of agricultural development in rural areas by Balinese proposals have become widespread public attention. Some impersonal studies of Simantri from various aspects have become the basis for providing confidence for long-term efforts towards food self-sufficiency, animal feed, organic fertilizer, energy needs and at the base is the welfare of farmers. Through imperial approaches and studies in several Simantri activity locations, it partially illustrates that the efforts made to develop agriculture in rural areas through Simantri activities provide great hope for the prosperity for farmers and rural communities [2].

The management of Bali Cattle Breeding Farms is one of the sub-systems of Simantri which plays an important role in measuring the success of the implementation of Simantri to farmers. It cannot be separated from the role of Bali cattle breeding farms as a sub system of Simantri, especially regarding the management of cattle breeding.

In some multiple-variable analyzes, the data matrix eigen structure is important. This eigen structure is stated in eigen roots and eigenvectors. A matrix consisting of observations of each object with $\mathrm{p}$ variables, is transformed into $\mathrm{Z}=\mathrm{X} \varphi$, where $\left.\Phi=\left(\varphi_{1}, \varphi_{2}, \ldots, \varphi_{\mathrm{p}}\right)\right)$ are 
orthogonal matrices in the form of pxp and $\varphi \mathrm{i}$ are eigenvectors of $\mathrm{X}^{\prime} \mathrm{X}$.

A square matrix with the order $\mathrm{n} x$ $\mathrm{n}$, for instance, $\mathrm{A}$ and a column vector $\mathrm{X}$. Vector $\mathrm{X}$ is a vector in Euklidian space $R^{n}$ that is connected by an equation: $A X=\lambda X$ where $\lambda$ is a scalar and $\mathrm{X}$ is a vector that is not zero Scalar $\lambda$ is called the Eigen value of matrix A. Eigenvalues is the characteristic value of a square matrix.

Matrix $\mathbf{A} \epsilon \mathbf{R}^{\mathbf{n x n}}$ stated to be symmetrical if it is $\mathrm{A}^{\prime} \mathrm{A}$ and matrixA $\mathbf{A} \mathbf{R}^{\mathbf{n x n}}$ stated to be orthogonal if $\mathrm{AA}^{\prime}=\mathrm{A}^{\prime} \mathrm{A}=\mathrm{I}$. It is clear that $\mathrm{A}$ is not singular with $\mathrm{A}^{-1}=\mathrm{A}^{\prime}$

Matrix $\mathbf{A} \epsilon \mathbf{R}^{\mathbf{n x n}}, \mathbf{A}=\left(\mathbf{a}_{\mathbf{i j}}\right)$ stated to be diagonal matrix if $\mathbf{a}_{\mathbf{i j}}=\mathbf{0}, \mathbf{i} \neq \mathbf{j}$. Diagonal matrix $\mathrm{A}$ can be also written as $\mathrm{A}=$ $\operatorname{diag}\left(\mathbf{a} 1, \mathbf{a} 2, . . . . . ., \mathbf{a}_{\mathbf{n}}\right)$, witha1, a2,......., an are theelements on the main diagonal.

Symmetrymatrix A can be stated as $\mathrm{A}=\mathrm{VDV}^{\prime}$, with $\mathrm{V}$ as orthogonal matrix and $\mathrm{D}$ as diagonal matrix.

The normu inEuklidianSpace $R^{n}$, if $\mathbf{u}=\left(u_{1}, u_{2}, u_{3}, \ldots, u_{n}\right)$, so the norm is: $|\bar{u}|=\sqrt{u_{1}^{2}+u_{2}^{2}+u_{3}^{2}+\ldots+u_{n}^{2}}$

And if the vectoru and vector $\mathbf{v}$ inEuklidianSpace $R^{n}$, so the space between vector $\mathbf{u}$ and $\mathbf{v}$ can be stated as follows:

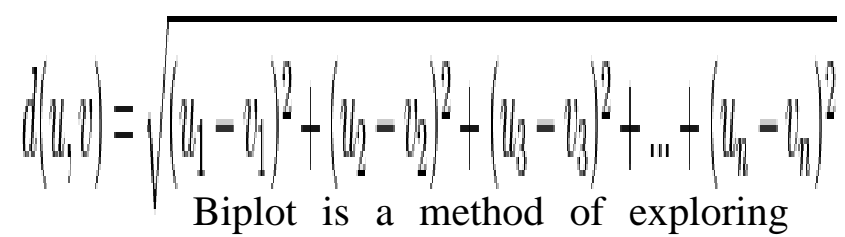
multiple data analysis that can give a graphical picture of the proximity between objects, variable variability, a correlation between variables, and the relationship between variables with objects. In addition, the biplot analysis is used to describe the relationship between variables and objects that are in a high-dimensional space into a two-dimensional space. From this, three approach matrices obtained related to data, variables, and objects. Suitability measure of the three matrices stated [3].

A graphical demonstration is expected to obtain an overview of objects, such as proximity between objects, and an overview of variables, both about diversity and correlation, and the relationship between objects with their variables. [4]. Biplot demonstration with factor analysis to describe rows (objects) and columns (variables) in the data matrix together in a low-dimensional graph usually using varimax rotation.Mattjik and Sumertajaya [5] reported that variables will be described as directed lines. Two variables that havea high positive correlation will be described as two lines in the same direction, or the ones which form a narrow-angle. Meanwhile, two variables 
that have high negative correlation are represented in the form of two lines in the opposite direction or the ones which form a blunt angle. While the two uncorrelated variables will be described in the form of two lines with angle closed to 90 (right angle). Variables with small diversity described as short vectors while large variable variants described as long vectors. Whereas proximity between objects, two objects with the same characteristics will be described as two points whose positions are close. Objects that are in the direction of the direction of variable claimed as the ones with higher value (above the average). Conversely, if other objects located in the opposite of it, those have a lower value (below the average). On the other hand, objects located almost in the middle have a value close to the average. Changes in the angle and direction of the variable arrows as well as changes in the location of coordinates of objects happened by rotating the Biplot analysis.Promax rotation (90) can be the factor of the changes [6]. The location of the coordinates of variables will be divided into 3 quadrants namely quadrants I, II and IV [7][8]. Rotation selection in the Biplot analysis aims to get more communicative information and be easier to evaluate the data being analyzed.

Based on the description above, it was desirable to know the difference between Norotate Rotation and Promax Rotation (90) of Biplot Simulation so it was expected to obtain communicative information about the management of Bali Cattle Breeding Farms at Livestock groupsin Simantri in Badung Regency, Bali. Both rotations provided different information in terms of explaining the position of Bali Cattle Breeding Farms management and Livestock groups on the four quadrants, then more communicative rotation had been selected. Two or more Livestock groups whose managements were almost the same described as two points or more adjacent positions, whereas two or more Livestock Groups with different managements described as two or more points far apart. While the location of Cows, Calves, Feeds, Cowshed and Environmental Managements used to illustrate the closeness of relationships and variations between them. This information used to determine which Livestock groups had good livestock management and vice versa.

\section{MATERIALS AND METHODS}

This study was a descriptive qualitative verification study carried out by purposive sampling to assignBadung regency as a sample out of 8 regencies in Bali. Saturated sampling group conducted to carry outsample group of Bali cattle 
breeders who took part in the Simantri program.

Data collected from all members of the livestock group at Simantri in Badung Regency, as a sub-system of the implementation of Simantri. The datacollected related to the management of their cattle farms.

From 5 research variables; Cows, Calves, Feed, Cowshed and Environmental Management, there were 55 management components of those variables. The Cows management component consisted of 13 components, starting from the selection of the seeds, the mother started to lust, the first child born as well as the death of the child tothe mother's behavior towards thenewborn calf. While the Calves management consisted of 12 components, ranging from the treatment of newborn calves, cutting the umbilical cord, the $Y i j=\frac{\sum_{1=1}^{5} \sum_{j 1}^{r} Y i j}{\max \text { imun_score }} \times 100$

\section{Data analysis}

The data collected were analyzed by factor analysis based on the correlation between variables so that the correlation matrix and its significance testing were mother fed the calf and gavecholestrumto the calf was weaned. On the other hand, Feed Management consisted of 8 components, starting from the type of feed given, the feeding time, and the frequency of feeding to the supplementary feed. Moreover, Cowshed management consisted of 7 components, ranging from the roof of the cage and the floor of the cage, the places where to eat and drink to the cleanliness of the cage. And the last, for the Environmental Management, it consisted of 15 components, ranging from waste storage, waste treatment, and wasteprocessing equipment to the marketing of waste processing products.

This study had 47 observation objects (livestock groups), and the data on each observation object (Livestock groups) processed by the formula:

$\mathrm{Y}_{\mathrm{ij}}$ : Data on the variable $\mathrm{i}(\mathrm{i}=1,2,3,4,5)$ and the component to $\mathrm{j}(\mathrm{j}=1,2,3, \ldots, \mathrm{r})$. The data showed on Table 1.

obtained. The eigenvector determined by the relation $\mathbf{R} \mathbf{x}_{\mathbf{o}}=\lambda \mathbf{x}_{\mathbf{0}}, \quad \operatorname{sof}(\mathbf{x})=\mid \mathbf{R}$ $\lambda \mathbf{I} \mid=\mathbf{0}$. So, $\mathrm{f}(\lambda)=0$ called as the eigen equation of matrix $R$, the root of this equation called as the eigenroot of matrix $\mathrm{R}$ and the vector corresponding to the eigen root called as eigenvector. 
Table 1. Bali Cattle Breeding Farm Management Data on Livestock Groups at Simantri in Badung Regency, Bali.

\begin{tabular}{|c|c|c|c|c|c|c|}
\hline \multirow[b]{2}{*}{ Livestock groups } & \multicolumn{5}{|c|}{ Management of } & \multirow[b]{2}{*}{ Mean } \\
\hline & Cows & Calves & Feed & Cowshed & Enviromen & \\
\hline Sami Polih & 92.31 & 100.00 & 81.25 & 92.86 & 83.33 & 89.95 \\
\hline Banyu Sari & 84.62 & 95.83 & 75.00 & 100.00 & 90.00 & 89.09 \\
\hline Taman Sari & 84.62 & 79.17 & 100.00 & 92.86 & 83.33 & 87.99 \\
\hline Dharma Pertivi & 76.92 & 79.17 & 75.00 & 100.00 & 96.67 & 85.55 \\
\hline BuanaGiri & 92.31 & 100.00 & 62.50 & 78.57 & 93.33 & 85.34 \\
\hline GemaMakmurSejati & 88.46 & 100.00 & 68.75 & 100.00 & 66.67 & 84.78 \\
\hline GemaUnggul Sari & 88.46 & 100.00 & 62.50 & 78.57 & 93.33 & 84.57 \\
\hline DarmaLaksana & 84.62 & 100.00 & 68.75 & 85.71 & 83.33 & 84.48 \\
\hline Mas Sari & 92.31 & 100.00 & 56.25 & 100.00 & 73.33 & 84.38 \\
\hline PancaUripMertasari & 76.92 & 75.00 & 81.25 & 92.86 & 93.33 & 83.87 \\
\hline Dewi Sari & 88.46 & 83.33 & 75.00 & 100.00 & 70.00 & 83.36 \\
\hline Getasan & 69.23 & 75.00 & 75.00 & 100.00 & 93.33 & 82.51 \\
\hline BuanaMekar & 73.08 & 75.00 & 81.25 & 85.71 & 96.67 & 82.34 \\
\hline Pula Kerti & 61.54 & 87.50 & 75.00 & 100.00 & 83.33 & 81.47 \\
\hline Sari Merta Pertiwi & 73.08 & 79.17 & 81.25 & 92.86 & 80.00 & 81.27 \\
\hline Rare Angon & 57.69 & 83.33 & 75.00 & 100.00 & 90.00 & 81.21 \\
\hline BalaAngon & 80.77 & 100.00 & 81.25 & 92.86 & 50.00 & 80.98 \\
\hline WerdiBuana & 73.08 & 70.83 & 87.50 & 92.86 & 76.67 & 80.19 \\
\hline Branjungan & 76.92 & 79.17 & 68.75 & 85.71 & 80.00 & 78.11 \\
\hline Tedung Sari & 53.85 & 79.17 & 75.00 & 85.71 & 86.67 & 76.08 \\
\hline Sukamaju & 76.92 & 54.17 & 75.00 & 100.00 & 66.67 & 74.55 \\
\hline CaturEka Sari & 69.23 & 58.33 & 75.00 & 92.86 & 73.33 & 73.75 \\
\hline Merta Jaya & 73.08 & 54.17 & 68.75 & 78.57 & 93.33 & 73.58 \\
\hline PucakTedung Sari & 50.00 & 75.00 & 68.75 & 85.71 & 86.67 & 73.23 \\
\hline Tri Mandala Sari & 65.38 & 50.00 & 75.00 & 92.86 & 80.00 & 72.65 \\
\hline ManikTirtaRahayu & 69.23 & 70.83 & 75.00 & 92.86 & 50.00 & 71.58 \\
\hline MertaJati & 76.92 & 62.50 & 56.25 & 78.57 & 83.33 & 71.52 \\
\hline Babakan Sari Sangeh & 80.77 & 41.67 & 68.75 & 85.71 & 76.67 & 70.71 \\
\hline Dharma Karya & 69.23 & 45.83 & 62.50 & 85.71 & 86.67 & 69.99 \\
\hline Wanasari & 80.77 & 45.83 & 62.50 & 78.57 & 80.00 & 69.53 \\
\hline KaryaMesari & 61.54 & 54.17 & 68.75 & 92.86 & 63.33 & 68.13 \\
\hline Sari Lestari & 69.23 & 58.33 & 68.75 & 92.86 & 50.00 & 67.83 \\
\hline Taman WijayaKusuma & 57.69 & 66.67 & 43.75 & 92.86 & 73.33 & 66.86 \\
\hline KarangAyu & 50.00 & 29.17 & 81.25 & 85.71 & 83.33 & 65.89 \\
\hline Tunjung & 53.85 & 41.67 & 81.25 & 78.57 & 70.00 & 65.07 \\
\hline Gading Sari & 65.38 & 54.17 & 50.00 & 85.71 & 66.67 & 64.39 \\
\hline KertaBuana Sari & 61.54 & 58.33 & 62.50 & 71.43 & 66.67 & 64.09 \\
\hline Amerta Jaya & 69.23 & 33.33 & 56.25 & 64.29 & 93.33 & 63.29 \\
\hline Pertivi Tani & 57.69 & 58.33 & 62.50 & 100.00 & 36.67 & 63.04 \\
\hline GelisNadi & 53.85 & 29.17 & 81.25 & 85.71 & 63.33 & 62.66 \\
\hline Gata Saga & 57.69 & 37.50 & 62.50 & 71.43 & 76.67 & 61.16 \\
\hline CakraBuana & 61.54 & 50.00 & 62.50 & 64.29 & 63.33 & 60.33 \\
\hline MertaBumi Sari & 73.08 & 41.67 & 56.25 & 57.14 & 66.67 & 58.96 \\
\hline Mekar Sari & 84.62 & 50.00 & 56.25 & 50.00 & 46.67 & 57.51 \\
\hline Sri Sedana & 65.38 & 37.50 & 62.50 & 100.00 & 20.00 & 57.08 \\
\hline ManikEkaNadi & 53.85 & 45.83 & 56.25 & 64.29 & 60.00 & 56.04 \\
\hline MertaNadi & 80.77 & 50.00 & 68.75 & 42.86 & 36.67 & 55.81 \\
\hline KertiBuana & 80.77 & 33.33 & 68.75 & 71.43 & 13.33 & 53.52 \\
\hline Mean & 71.63 & 65.19 & 69.66 & 85.42 & 72.71 & 72.92 \\
\hline
\end{tabular}

The demonstration of the coordinate of variable i (Vi) taken from 2 eigenvectors which corresponded to the first largest eigen root (component 1 ) as the $\mathrm{X}$ axis (abscissa) and the second largest eigen root (Component 2) as $\mathrm{Y}$ (ordinate). Rotations used were Norotate Rotation and Promax Rotation (90). Norotate Rotation: the angle between variables describes the magnitude of the correlation between Cows, Calves, Feeds, Cowshed and Environmental Management. If the angle between variables forms a sharp angle, then the correlation between the variables is positive while if it forms a blunt angle so the correlation is negative. When the 
sharp angle is close to $0^{\circ}$ (almost coincide) so the correlation is close to 1 , on the contrary if the angle between variables is close to $90^{\circ}$ (close to the right angle) then the correlation is close to 0 (null). While Promax Rotation (90) divides the location of variables in 3 quadrants, the angle between variables cannot describe the magnitude of the correlation, but only illustrates the closeness of the relationship. Moreover, the location of the coordinates of the observation objects (Livestock groups) determined based on the Scores Method Regression Factor Analysis, the score factor 1 was as abscissa and the score factor 2 was as coordinate. Biplot obtained based on a graphical picture in one space with two dimensions to the coordinate of variables (Management of Cattle Breeding) and the object of observation (Livestock groups).
Analysisprocedures using Statistical

Product and Service Solutions Version 22.

\section{RESULTS AND DISCUSSION}

The total variance explained with norotate rotation and promax rotation (90) indicated that the coefficient of goodness was $64.718 \%$ of the 5 variables (Management of Bali cattle Breeding Farm) which could be found in biploteigen space with two dimensions. (Table 2.). This showed that retrieving two main components could explain data of $64.718 \%$. So that the biplot analysis with norotate rotation and promax rotation (90) in this study provided a fairly good data presentation about the information on Bali Cattle Breeding Farm Management for the Livestock groups at Simantri, Badung Regency, Bali.

Table 2. Total Variance Explained Management of Bali Cattle Breeding Farm

\begin{tabular}{ccccccc}
\hline Component & \multicolumn{3}{l}{ Initial Eigenvalues } & \multicolumn{3}{c}{ Extraction Sums of Squared Loadings } \\
\cline { 2 - 7 } & Total & $\begin{array}{c}\text { \% of } \\
\text { Variance }\end{array}$ & $\begin{array}{c}\text { Cumulative } \\
\%\end{array}$ & Total & $\begin{array}{c}\text { \% of } \\
\text { Variance }\end{array}$ & Cumulative \% \\
\hline 1 & 2.093 & 41.857 & 41.857 & 2.093 & 41.857 & 41.857 \\
2 & 1.143 & 22.862 & 64.718 & 1.143 & 22.862 & 64.718 \\
3 & 0.844 & 16.888 & 81.606 & & & \\
4 & 0.649 & 12.989 & 94.595 & & & \\
5 & 0.270 & 5.405 & 100.000 & & & \\
\hline
\end{tabular}

Extraction Method: Principal Component Analysis.

Biplot simulation with norotate rotation showed that the coordinates of variables (Management of Bali Cattle Breeding Farm) and observation object (Livestock groups) had no boundaries
(Norotate Rotation) as can be seen in Figure 1. Figure 1 shows that the angle between vector components of management of Bali Cattle Breeding Farm namely Cows, Calves, Feed, Cowshed, and 
Environmental, showed the magnitude of the correlation between the vectors and the length of them referred to the diversity between vectors of Cows, Calves, Feeds, Cowshed and Environmental. The sharper the angle between variables is, the greater the correlation will be while the closer the angle to the right angle $\left(90^{\circ}\right)$, the smaller the correlation (near zero) will be. And if the angle is blunt $\left(>90^{\circ}\right)$, the correlation will be negative. Whereas the longer the norm is, the greater the diversity will be. In contrast, the shorter the norm is, the smaller the diversity will be.
The coordinates of the observation object (Livestock groups) spread across 4quadrants on the two axes.Livestock groups with high Cows and Calves scores approaching 100 located in quadrant I, while the low ones located in quadrant III. While for Livestock groups whose scores of Feed, Cowshed and Environmental were high (close to 100) located in quadrant III and the ones with lower scores located in quadrant I. So the closer the locations of Livestock groups to the vector directions, the higher the score will be, and vice versa.

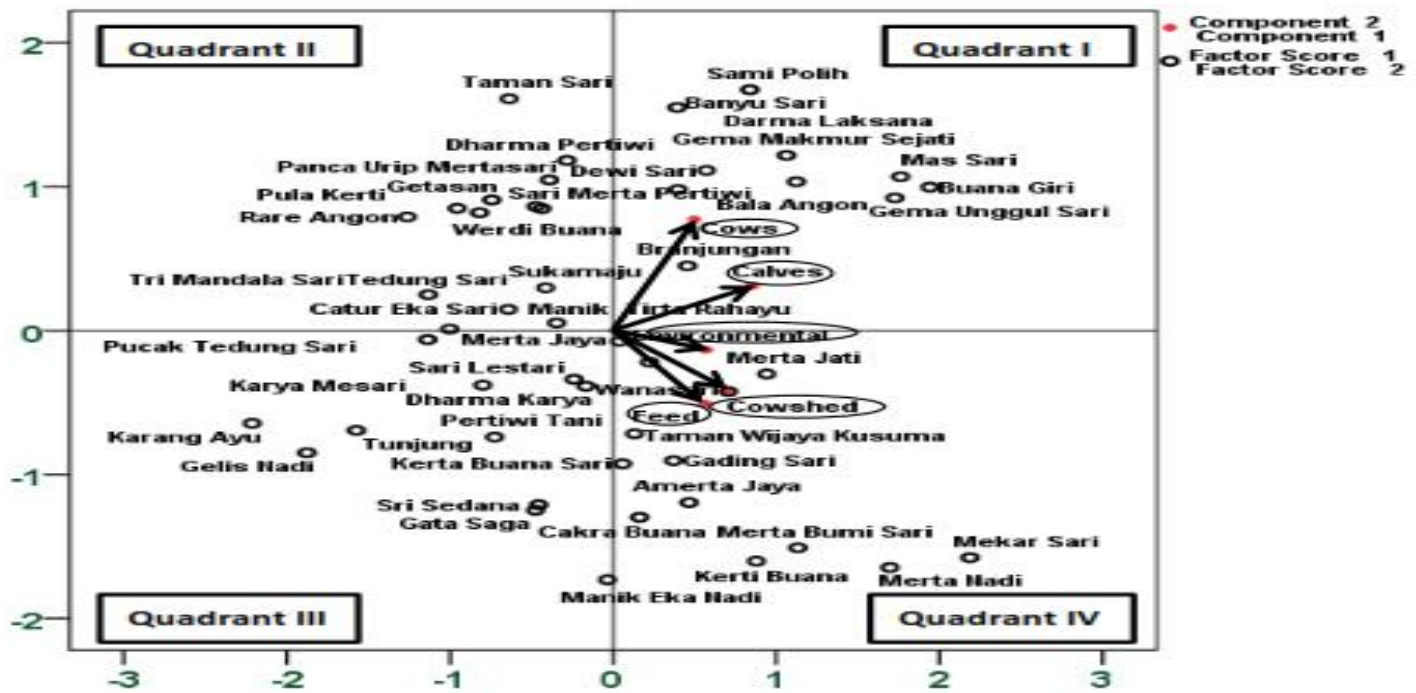

Figure 1. Biplot Simulation with Norotate Rotation

Biplot simulation with Promax Rotation (90) which showed the relation of the coordinates of variables (Bali Cattle Breeding Farm Management) and observation objects (Livestock groups) can be seen in Figure 2. Figure 2 shows that the angle between vector components of Bali Cattle Breeding Farm management namely Cows, Calves, Feed, Cowshed and
Environmental, could not be used to show the magnitude of the correlation between those vectors, but only to show the closeness of the relationship between variables and the norms of Bali Cattle Breeding Farm. Nevertheless, it showed the diversity between vectors of Cows, Calves, Feeds, Cowshed, and Environmental. Promax rotation (90) 
caused changes in the directions of the vectors, thus causing changes in angle between vectors of Cows, Calves, Feeds, directions of the vectors divided into 3 quadrants so that the angle between the vectors could no longer describe the magnitude of the correlation.

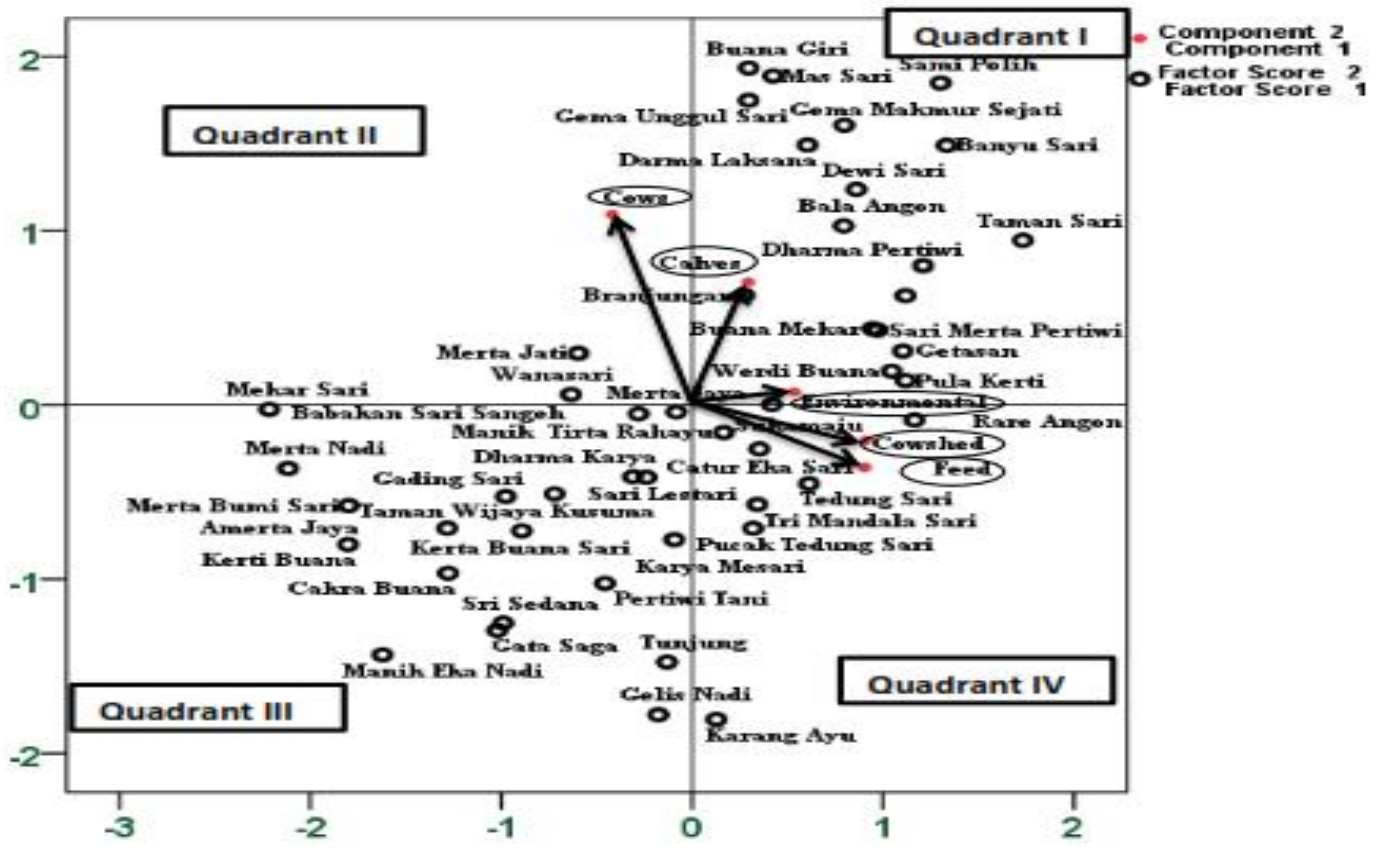

Figure 2. Biplot simulation with Promax Rotation (90).

The coordinates of Livestock Groupswith Promax

Rotation

(90)remained scattered in the 4 quadrants on the two axes, but there were changes of the coordinates following the direction of Cows, Calves, Feed, Cowshed and Environmental Management. Two Livestock groups located in quadrant II are the ones that scores were quite high or above average, but the Feed scores and Cowshed scores were quite low or below average namely Livestock Group MertaJati and Wanasari. While in quadrant I, there were 16 Livestock Groups which had high Calves and Environmental scores or above the average. Furthermore, in quadrant IV,there were 7 Livestock Groups with high scores of Feed and Cowshed, but low score of Cows namely Rare Angon, Tedung Sari, PucakTedung Sari, Tri Mandala Sari ,CaturEka Sari and KarangAyu. There were also Livestock Groups located in quadrant III (22 Livestock Groups) which were not in line with the four components of Bali Cattle Breeding Farm Management, namely Cows, Calves, Feeds, Cowshed and Environmental. So, they were the ones with low scores of the four components or below the average.

The results showed that both norotate rotation and promax rotation (90) 
gave the same good coefficient, which was $64.718 \%$, regardless of the correlation of the directions and magnitudes of correlation between Cows, Calves, Feed, Cowshed, and Environmental management. In that case, Promax rotation (90) was more appropriate to be used in identifying the location of Livestock Groups' coordinates in the 4th quadrant. Finch and Holmes [9] reported that Varimax and Promax rotations could both restore the structure of the underlying factors, despite the correlation between these factors, althoughpromax rotation was better to be used in identifying the presence of simple structures. In addition, Finch and Holmes [10] reported that mixed performance patterns between various rotations with the Equamax orthogonal were consistently near the top in terms of correct grouping and order indicators, and Facparsim orthogonal performs well with more indicator observations. Certain data features will support the use of one or more methods studied here. Varimax and Promax rotations must be used and taken into account since they often do not produce optimal results in terms of reflecting the structure of the underlying factors accurately. The use of promax rotation (90) in the biplot simulation results the locations of variables which divided into 3 quadrants namely quadrants I, II and IV so that it makes describing differences of growth rate characteristics of the variables easier [7][8].

Biplot simulation with Promax Rotation (90) can be chosen to obtain the information about management of Bali Cattle Breeding Farm in Livestock Groups inSimantri, Badung Regency, Bali. The results showed that most of the Livestock Groups were in quadrant III (22 Livestock Groups) which indicated that the farm managements were still below the average. This led to the situation wherethe management in Livestock Groups in Badung Regency need to be improved by following intensive counseling to farmers in Livestock Groups. The selection of superior cow seedlings, good housing system, and the availability of sufficient animal feed requires special attention from the government, so that the government's hope for the farmers' welfare through the Simantri program can become a reality. Livestock Groups which have carried out good livestock management can be an example for others in other Simantri to improve their management system. This is important to accelerate the development of rural communities through Simantri activities. Every Livestock Group must keep its entrepreneurial spirit up and be creative by having a good mindset such as looking for information from Livestock Groups whose managements have been 
carried out properly so that it can be motivation to be better. It has a positive effect on the success of Livestock Group, the best entrepreneurial spirit is by havingflexibility in socializing [11]. the studies of Livestock Groups in several Simantri activity locations which done partially illustrated that the efforts made to develop agriculture in rural areas through Simantri activities had provided great hope for better prosperity for farmers and rural communities in the future [2].

\section{CONCLUSION}

The angle between vectors in norotate rotation illustrates the magnitude of the correlation between the management of Cows, Calves, Feeds, Cowshed, and Environmental, while the promax rotation (90) only describes the closeness of the relationship. Vector direction of management of Cows, Calves, Feed, Cowshed, and Environmental and the coordinates of Livestock Group on Promax rotation (90) give more specific results compared to Norotate Rotation. The Livestock Groups which are in quadrant I and IV have carried out fairly good livestock management. While the ones in the quadrant II had good management for the Cows, but bad for Calves and Feed and for the ones in quadrant III, they generally do poor livestock management.

\section{SUGGESTION}

Need to evaluate on the management of Cows, Calves, Feeds, Cowshed and Environmental at Livestock Groups atSimantri, Badung regency, Bali by conducting a biplot simulation with the use of Promax Rotation (90). In a Biplot Simulation, the improvement of livestock management should be carried out for the Livestock Groups in quadrant III by using Promax Rotation (90).

\section{REFERENCES}

[1] DISTAN Provinsi Bali .2014. Kegiatan Sistem Pertanian Terintegrasi (Simantri) di Provinsi Bali. Denpasar, Bali, Indonesia.

[2] Anugrah IS, Sarwititi S, Suradisastra K, Purnaningsih N. 2014. Integrated Agriculture System (Simantri): Its Concept, Implementation, and Role in Agricultural Development in Bali Provinc.Volume 32 No. 2, Desember 2014: 157 - 176.

[3] Gabriel KR. 2002. Goodness of fit of biplots and correspondence analysis Biometrika, 89(2), 423-436

[4] Solimun N, Rinaldo AA. 2008. Structural Equation Modeling Approach PLS and SEM. Faculty of Science and the Graduate Program UB.

[5] Mattjik AA, SumertajayaIM. 2002. Perancangan Percobaan dengan Aplikasi SAS dan minitab, Jilid I.

[6] Sampurna IP, Saka IK, Oka IGL, Sentana P. 2013. Biplot Simulation of Exponential Function to Determine Body Dimensions' Growth Rate of Bali Calf.Canadian Journal on Computing in Mathematics Natural Sciences Engineering ane Medicine.Vol. 4. No. 1. 
[7] Sampurna P.2016.Biplot Simulation to Determine the Growth Rate of Body Dimension in Local Bali Ducks. Journal of Biometrics \& Biostatistics. Vol.7. Issue 6. J Biom-Biostat7: 284. DOI: $10.4172 / 2155-6180.1000284$.

[8] Sampurna IP, Nindhia TS. 2017. Bilot Simulation of Power Function to Determine Growth Rate of Animals. Indian Journal of Applied Researche (IJAR).Agriculturel.Vol. 7.Issue 6.

[9] FinchW, Holmes. 2006. Comparisonof the Performance of Varimax and romax Rotations: Factor Structure Recovery for Dichotomous Items. Journal of Educational Measurement
Volume 43 (1). DOI: 10.1111/j.17453984.2006.00003

[10] Finch W, Holmes. 2011. A Comparison of Factor Rotation Methods for Dichotomous Data. Journal of Modern Applied Statistical. Vol. 10: Iss. 2, Article 14.DOI: 10.22237/jmasm/1320120780

[11]Dananjaya IGAN. Suparta N, I Setiawan IGAP. (2014). The Influence of The Spirit of Entrepreneurship and Agribusiness Management Towards Success Gapoktan Simantri in Tabanan. Jurnal Manajemen Agribisnis Vol. 2, No. 2, Oktober 2014 ISSN: 2355-0759 